\title{
The Grain Yield Performance and Stability Characters of Several Spring Wheat Genotypes in Transylvanian Plain Conditions
}

\author{
Ionuț RACZ ${ }^{*}$, Rozalia KADAR ${ }^{1}$, Ovidiu Adrian CECLAN ${ }^{1}$, Diana HIRISCĂU ${ }^{1}$, Florin Dumitru BORA ${ }^{2}$, Laura \\ ŞOPTEREAN ${ }^{1}$ and Roxana CĂLUGĂR ${ }^{1,3}$ \\ ${ }^{1}$ Agricultural Research and Development Station Turda, Romania. \\ ${ }^{2}$ Department of Physico-Chemistry and Biochemistry. Research Station for Viticulture and Enology \\ Târgu Bujoru, Romania. \\ ${ }^{3}$ University of Agricultural Science and Veterinary Medicine Cluj Napoca, Romania \\ *corresponding author, e-mail: racz_ionut@yahoo.com
}

Bulletin UASVM series Agriculture 76(1) / 2019

Print ISSN 1843-5246; Electronic ISSN 1843-5386

DOI:10.15835/buasvmcn-agr: 2017.0045

\begin{abstract}
The current study presents some stability parameters (coefficient of variation, environment variation, regression coefficient, deviation from regression, coefficient of determination and ecovalence) of grain yields and the main components of its. Twenty-two spring wheat cultivars were tested in yield trials during three years being analyzed the number of grains per spike, thousand kernel weight and spike density The genotypes: Durom and Marcius indicated over the experimental years, a high stability for grain yield, based on three or more parameters $\left(\mathrm{CV}, \mathrm{s}^{2}, \mathrm{~b}, \mathrm{~s}_{\mathrm{d}}{ }^{2}\right)$ and a good adaptation. Corso and Henica genotypes have a good stability for number of grains per spike with a medium number of grains, and TD 1524-71 is the most unstable genotype for thousand kernel weight. Regarding the correlation between stability parameters for analyzing characters there is a different and additional reaction according to differently performance of genotype.
\end{abstract}

Keywords: grain yield, performance, stability, yield components

\section{Introduction}

the value of genotype is given by the productivity performance which involves his adaptability to different conditions. In the current global context, the yield performance and yield stability of cereals represent an important aspect and the increasing yield without affecting yield stability is a major challenge for wheat breeding (Mustățea et al., 2009). The global warming is characterized by frequently shifts of weather patterns and extreme climatic events (Lobell et al., 2012; Semenov and Shewry, 2011; Sillmann and Roeckner, 2008), subjecting genotypes to supplimentary stress. However, the intrinsic uncertainty of climate change predictions poses a challenge to plant breeders and crop scientists who have limited time and resources and must select the most appropriate traits for improvement (Foulkes et al., 2011; Semenov and Halford, 2009; Zheng et al., 2012) Genotype $\mathrm{x}$ environment interaction is a major problems being a challenge issue for plant breeders improving high-yielding, stable genotypes for variable environments (Cruz et al., 2012; Barros et al., 2010; Kara, 2000). In the current population explosion, the food safety is seriously tried, caused especially by reduction of agricultural areas (Reisch et al., 2013). Even though the winter form of wheat is predominating 
in Europe due the favorable conditions, many times caused by the lack of soil water or due to the late issuance of land for previous crop which make impossible establishment of a crop in optimal conditions, the spring wheat occur important areas (Semenov et al., 2014). Spring wheat yield capacity is often comparable with the winter crop, especially when in the fall of the year climatic conditions are unfavorable to grow and to develop the first stages of winter wheat plants.

Li et al. (2014) characterized the spring wheat ecotype as an optimal wheat genotype with a maximum potential for grain yield production under optimal growing conditions, compared with his short vegetation period.Wheat grain yield is a complicated quantitative parameter and it is the product of its interaction with environment and several yield attributes affecting grain yield (Anwar et al., 2009). Grain yield is highly affected by environmental stresses like drought stress caused by unavailability of water, less rainfall and heat stress because over $50 \%$ of the total wheat is sown late which results in terminal heat stress. The interaction between the traits of grain yield with the environment is very complex and nonlinear making the objective assessment of the cultivar very difficult (Tsenov et al., 2014) There is great variability in the expression of many characteristics related to wheat quality and yield in different environments which accounts for the environmental effect on these characteristics (Castillo et al., 2012).

High temperature accompanied with drought stress determine a reduced duration of maturation, grain filling period, grain yield capacity, mean grain weight per spike, grain number per spike and 1000 kernel weight (Kaur and Behl, 2010).

The stability parameters are specific to genetic value of each genotype and depend on the genotypes adaptability performance (Dewi et al., 2014). If the main components of grain yield have some different stability parameters, the grain yield stability is the one that offers a complete information. The stability parameters offer important data about the performance of genotype in relationship with the environment conditions; both mean yield and stability might be considered simultaneously to exploit the useful effect of $G^{x}$ E interaction (Bantayehu, 2009; Saad et al., 2013). The knowledge of behavior of the main yield components, such as the number of grains per spike, thousand kernel weight and the spikes density per square meter helps to identify or setting the productivity elements allowing outside intervention in order to improve these characters.

The mean performance and the coefficient of regression were used as production response indices, while the deviation from regression, the coefficient of determination and the ecovalence were used as stability indices (Showemimo, 2007).

The aim of this study was to estimate the capacity of adaptability of some spring wheat varieties reflected in grain yield and yield components stability under three different years conditions.

\section{Materials and methods}

Twenty-two spring wheat varieties of different origins (Romania, Rusia, Hungary and Poland) were tested in the environmental conditions from Transylvanian Plain, Romania (520.5 mm average annual precipitation, $9.1{ }^{\circ} \mathrm{C}$ multi-annual mean temperature, longitude $23^{\circ} 47^{\prime}$; latitude $46^{\circ} 35^{\prime}$; altitude $427 \mathrm{~m}$ ). The study was realized during three years (2011-2013) in the yield trial field grown in randomized complete block design in three replications in Wheat Breeding Department of Agricultural Research and Development Station from Turda (Cluj, Romania). Even if the sum of precipitation is almost the same in the studied years (Tab. 1) the allocation of those by critical vegetation periods was different and the highest yield was recorded in 2012.

The yields and the main yield components as: number of grains/spike, spike density and thousand kernels weight were analyzed by ANOVA.

Characterization of genotypes stability for mentioned characters was achieved using the following statistics parameters: coefficient of variation $(\mathrm{cv} \%)$ :

c) $\%=\frac{s \times 100}{\bar{x}}$

the environment variance $\left(s^{2}\right)$ :

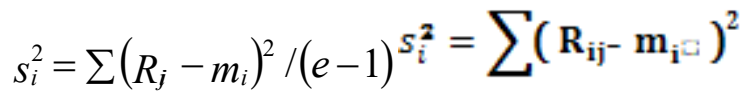

where $R_{i j}$-observed genotype yield response in the environment $j$,

$m_{i}$ - genotype mean yield across environments and $e$ - number of environments.

Highest stability is $\mathrm{s}^{2}=0$. 
Table 1. The rainfall conditions during experimental years

\begin{tabular}{cccccccc}
\hline \multirow{2}{*}{$\begin{array}{c}\text { Year/ } \\
\text { Month }\end{array}$} & $\mathrm{mm}$ & $\begin{array}{c}\text { Deviation } \\
\text { from mean } \\
\pm\end{array}$ & $\mathrm{mm}$ & $\begin{array}{c}\text { Deviation from } \\
\text { mean } \pm\end{array}$ & $\mathrm{mm}$ & $\begin{array}{c}\text { Deviation } \\
\text { from mean } \\
\pm\end{array}$ & $\begin{array}{c}\text { Multi-annual } \\
\text { mean }\end{array}$ \\
\hline March & 15.3 & -7.8 & 5.3 & -17.8 & 57.9 & 34.8 & 23.1 \\
\hline April & 22.6 & -22.1 & 78.4 & 33.7 & 53.3 & 8.6 & 44.7 \\
\hline May & 41.4 & -26.3 & 89.2 & 21.5 & 79.3 & 11.6 & 67.7 \\
\hline June & 116.8 & 32.3 & 67.4 & -17.1 & 86.2 & 1.7 & 84.5 \\
\hline July & 130.4 & 53.7 & 52.4 & -24.3 & 37.6 & -39.1 & 76.7 \\
\hline Sum & 326.5 & & 292.7 & & 314.3 & & 296.7 \\
\hline
\end{tabular}

regression coefficient [(b) Finlay and Wilkinson (1963)]:

$\frac{\sum x y-\frac{\sum \mathbf{x} \Sigma \mathbf{y}}{\mathbf{N}}}{\left(\sum x^{2}, \frac{\sum x^{2}}{N}\right)} \quad b_{y / x}=\frac{\sum x-\frac{\sum x \times \sum y}{N}}{\left(\sum x^{2} \times \frac{\sum x^{2}}{N}\right)}$

The coefficient of regression and the mean yield in all environments were used to classify the varieties for stability. Finlay and Wilkinson (1963) concluded that a variety with $b=1$ has average stability. A variety with $b=1$ and above average yield was considered having general adaptation, while a variety with $\mathrm{b}=1$ and below average yield was classified as poorly adapted to all environments. $\mathrm{b}>1$ describes a variety with increased sensitivity to environmental changes, having lower stability and greater adaptability to high yielding environments. Regression coefficient less than 1.00 describes a variety with greater resistance to environmental changes, therefore, it has above average stability and specific adaptability to low yielding environments (Wu et al., 2014).

- deviations from regression [(Eberhart and Russell,1966]:

$s_{d}^{2}=\frac{1}{n-2}\left[\left(\sum F_{j}^{2}-\frac{\left(\sum F_{i j}\right)^{2}}{n}\right)-\frac{\left(\sum F_{j} t_{j}\right)^{2}}{\sum t_{j}^{2}}\right]-\frac{\sigma_{E}^{2}}{r}$

where $\mathrm{n}=$ number of environments, $\mathrm{r}=$ number of repetition, $=$ the variance of error, $=$ the mean of genotype $i$ in environment $j$, = the effect of $j$ environment.
A better stability of genotype is given by a small value of deviations from regression, approaching 0 .

coefficient of determination ( $\mathrm{r}^{2}$ - Pinthus, 1973):

$r_{i}^{2}=1-\frac{s_{\dot{d}}^{2}}{s_{\dot{x}}^{2}}$

Pinthus (1973) proposed to use the coefficient of determination () instead of deviation of deviation mean squares to estimate stability of genotypes, because is strongly related to deviation mean squared (Becker, 1981).

Coefficients of determination $\left(r^{2}\right)$ were obtained from the linear regression of individual yield in different environments on the mean yield of all the genotypes in each environment. Greatest stability is $r^{2}=1$.

- Wricke's ecovalence $\left(W^{2}\right)$ :

$W_{i}^{2}=\sum\left(R_{\boldsymbol{j}}-m_{i}-m_{j}+m\right)^{2}$

where $R_{i j}$ is the observed yield response (averaged across experiment replicates), $m_{i}$ and $m_{i}$ correspond to previous notations, and $m$ is the grand mean. Greatest stability is $W^{2}=0$.

Wricke's ecovalence (1962) evaluates stability on the basis of each genotype contributions to the total GEI (genotype $\mathrm{x}$ environment interaction) sum of squares. The genotypes with a low $W_{i}$ value have a smaller deviation from the mean across environments and are thus more stable.

\section{Results and discussions}

The results from Tab. 2 highlighted the major influence of year growth conditions over the experimental years. The genotype influence is close to GE interactions which means that sensibility of cultivars was high, the grain yield or the other main yield components being dependent 
Table 2. Analysis of variance for grain yield and main yield components of 22 spring wheat genotypes tested across three years in Transylvanian Plain conditions (Turda)

\begin{tabular}{cccccc}
\hline Source of variation & df & Grain yield & Number of grain/spike & 1000 - kernels weight & Spike density \\
\hline Year & 2 & $120.82^{* *}$ & $240.31^{* *}$ & $504.73^{* *}$ & $6630.62^{* *}$ \\
\hline Genotype & 21 & $2.35^{* *}$ & $68.73^{* *}$ & $27.38^{* *}$ & $56.22^{* *}$ \\
\hline Year x genotype & 42 & $3.20^{* *}$ & $59.37^{* *}$ & $12.30^{* *}$ & $52.60^{* *}$ \\
\hline Total & 197 & & & & \\
\hline
\end{tabular}

Table 3. Grain yield and variation in studied spring wheat cultivars

\begin{tabular}{cccccc}
\hline \multirow{2}{*}{ Genotypes } & Average yield & 2011 & 2012 & 2013 & Amplitude* $^{*}$ \\
\cline { 2 - 5 } & & & $\left(\mathrm{t} \mathrm{ha}^{-1}\right)$ & & 4.46 \\
\hline Lona & 4.36 & 2.96 & 5.84 & 4.66 & 3.23 \\
\hline SG 106-01 & 4.32 & 2.87 & 6.65 & 3.56 & 4.56 \\
\hline Prif 3 & 4.27 & 2.60 & 6.52 & 4.07 & 5.01 \\
\hline Marcius & 4.26 & 2.17 & 5.70 & 4.01 & 3.23 \\
\hline Corso & 4.23 & 2.97 & 6.20 & 3.78 & 4.13 \\
\hline SG 5-01 & 4.21 & 2.66 & 6.20 & 3.71 & 3.31 \\
\hline PF 70-35-4 & 4.17 & 2.60 & 5.85 & 3.11 & 3.66 \\
\hline Jota & 4.16 & 3.51 & 5.94 & 3.35 & 4.10 \\
\hline Jara & 4.14 & 3.14 & 6.12 & 3.86 & 3.70 \\
\hline SG V 773 & 4.12 & 2.37 & 5.64 & 3.57 & 3.40 \\
\hline Henica & 4.09 & 3.06 & 5.67 & 3.03 & 3.18 \\
\hline Sigma & 4.07 & 3.52 & 5.67 & 3.12 & 3.66 \\
\hline Silva & 3.92 & 2.98 & 5.46 & 3.57 & 3.23 \\
\hline Pădureni & 3.87 & 2.60 & 5.30 & 3.34 & 3.72 \\
\hline Uralocica & 3.87 & 2.98 & 5.63 & 3.04 & 3.40 \\
\hline Beloterkovskaia & 3.84 & 2.86 & 5.62 & 3.38 & 2.94 \\
\hline GK Tavasz & 3.82 & 2.45 & 5.25 & 3.05 & 4.50 \\
\hline Mario & 3.77 & 3.02 & 5.00 & 3.75 & 3.22 \\
\hline Prif 4 & 3.75 & 2.51 & 5.63 & 3.61 & 2.51 \\
\hline TD 1524-71 & 3.67 & 1.78 & 5.19 & 3.17 & 3.16 \\
\hline Brome & 3.64 & 2.56 & 4.82 & & \\
\hline Durom & 3.63 & 2.90 & & & \\
\hline *including repetition & & & & \\
\hline
\end{tabular}

of climatic conditions. The lack of water or high temperatures during the main plant phenophases (emergence, heading, flowering, grain filling and maturity) reduced the performances of genotypes (number of grains per spike, weight of grains per spike and thousand kernel weight) and finally the grain yield.

The variation of grain yields in tested cultivars is presented in Tab. 3. Environmental conditions determined a large fluctuation for grain yield especially for Marcius variety whose grain yield has recorded a biggest amplitude (5.013 t/ $\left.\mathrm{ha}^{-1}\right)$.

The smallest amplitude was registered by Durom variety $\left(2.51 \mathrm{t} \mathrm{ha}^{-1}\right)$ but this reduced variation was caused by the poor potential of the genotype. The average capacity of spring wheat group for yield was between $2.5-4.0 \mathrm{t} \mathrm{ha}^{-1}$, but in favorable conditions the capacity of production of some genotypes can raise to 6-7 t ha-1. Similar results for grain yield were reported by Kiliç (2012) in a multi-environments study for twenty-five bread spring wheat genotypes. Large amplitude regarding grain yields was obtained by Sapega and Tursumbekova (2013) in an ample study with spring wheat varieties and their adaptability in contrasting conditions.

The coefficient of variability showed a high variability for all genotypes regarding the grain yield (tab. 4). The other stability parameters $\left(s^{2}\right.$, $\mathrm{b}, \mathrm{r}^{2}$ and $\mathrm{W}^{2}$ ) indicated a specific stability for each genotype. Regarding the stability of grain yield of the studied spring wheat genotypes, the stability parameters $s^{2}$ and $b$ indicated a high stability for Durom and Prif 4 varieties.

Based on Wricke's coefficient $\left(\mathrm{W}^{2}\right)$ the most stable varieties are GK Tavasz, Brome and Pădureni, and the most unstable genotypes are GK Marcius, followed by TD 1524-71 and Sigma. Amin 
Table 4. Several stability parameters of grain yield for 22 spring wheat genotypes

\begin{tabular}{cccccccc}
\hline Genotypes & $\begin{array}{c}\overline{\mathbf{x}} \overline{\mathbf{x}} \\
\mathrm{t} / \mathrm{ha})\end{array}$ & $\mathrm{CV}(\%)$ & $\mathrm{s}^{2}$ & $\mathrm{~b}$ & & $\mathrm{r}^{2}$ & $\mathrm{~W}^{2}$ \\
\hline Lona & 4.36 & 40.0 & 3. & 1.20 & 0.02 & 0.99 & 0.53 \\
\hline SG 106-01 & 4.32 & 33.1 & 2.0 & 0.94 & 0.23 & 0.91 & 0.95 \\
\hline Prif 3 & 4.27 & 45.0 & 3.7 & 1.32 & 0.10 & 0.98 & 1.44 \\
\hline Marcius & 4.25 & 47.0 & 4.0 & 1.35 & 1.48 & 0.95 & 2.24 \\
\hline Corso & 4.23 & 30.1 & 1.6 & 0.87 & 0.04 & 0.98 & 0.35 \\
\hline SG 5-01 & 4.21 & 39.2 & 2.7 & 1.14 & 0.05 & 0.99 & 0.39 \\
\hline PF 70-35-4 & 4.17 & 40.7 & 2.9 & 1.17 & 0.05 & 0.99 & 0.50 \\
\hline Jota & 4.16 & 33.9 & 2.0 & 0.91 & 0.32 & 0.87 & 1.35 \\
\hline Jara & 4.14 & 35.8 & 2.2 & 1.01 & 0.09 & 0.97 & 0.38 \\
\hline SG V 773 & 4.12 & 42.1 & 3.0 & 1.18 & 0.14 & 0.96 & 0.91 \\
\hline Henica & 4.09 & 32.6 & 1.8 & 0.89 & 0.17 & 0.93 & 0.79 \\
\hline Sigma & 4.07 & 33.5 & 1.9 & 0.87 & 0.37 & 0.84 & 1.65 \\
\hline Silva & 3.92 & 35.6 & 1.9 & 0.95 & 0.09 & 0.96 & 0.40 \\
\hline Pădureni & 3.88 & 36.5 & 2.0 & 0.97 & 0.06 & 0.98 & 0.23 \\
\hline Uralocica & 3.87 & 32.1 & 1.5 & 0.84 & 0.10 & 0.95 & 0.69 \\
\hline Beloterkovskaia & 3.84 & 37.5 & 2.1 & 0.98 & 0.09 & 0.96 & 0.37 \\
\hline GK Tavasz & 3.82 & 39.2 & 2.2 & 1.03 & 0.02 & 0.99 & 0.09 \\
\hline Mario & 3.77 & 34.8 & 1.7 & 0.86 & 0.20 & 0.91 & 1.00 \\
\hline Prif 4 & 3.75 & 31.3 & 1.4 & 0.78 & 0.13 & 0.92 & 1.04 \\
\hline TD 1524-71 & 3.67 & 47.8 & 3.1 & 1.15 & 0.39 & 0.90 & 1.81 \\
\hline Brome & 3.64 & 36.1 & 1.7 & 0.91 & 0.02 & 0.99 & 0.17 \\
\hline Durom & 3.63 & 27.9 & 1.0 & 0.69 & 0.03 & 0.98 & 1.11 \\
\hline Mean & 4.01 & 36.9 & 2.3 & 1.00 & 0.19 & 0.95 & 0.84 \\
\hline
\end{tabular}

et al. (2005) found for 10 spring wheat genotypes grown in 9 locations from Pakistan the regression coefficient $\left(b_{i}\right)$ value between 0.367 to 1.626 , and deviation from regression between 0.065-0.601.

The present results for grain yield are in accordance for one or more of the studied parameters $\left(C V, s^{2}, b_{1}, r^{2}\right.$ and $\left.W^{2}\right)$ have been reported by Kilic et al. (2010), Akcura et al. (2006) and Hugo Ferney et al. (2007).

The stability of grain yield depends on stability of the main elements of productivity (Yagdi, 2009; Andersen et al. 2011). Thus, the stability of number of grain per spike had small values to medium according to variability coefficient (tab. 5). The coefficient of variability for number of grains per spike ranged between 2.02 by Corso variety to 24.9 at TD 1524-71. Environmental variance $\left(\mathrm{s}^{2}\right)$ had oscillating values between 0.42 at the same Corso variety to 56.1 by Lona genotype, with an average value of this parameter by 24.1 units. Based on $b$ and $\mathrm{r}^{2}$ values the most stability genotype is Henica, followed by GK Tavasz and Corso varieties.

The values of deviations from regression for number of grains per spike $\left(\delta^{2}\right)$ also offers some additional information but somewhat different, such that relating to this parameter the GK Tavasz genotype are the most instable cultivars contrary with intercept appreciation, but in concordance with Wricke's coefficient.

Generally, thousand kernel weight is a stable character by winter wheat, but in case of spring wheat the variability of this character is fluctuating being dependent by environment conditions (Kaya and Akcura, 2014), especially rainfall. The large variation of coefficient of variability $(12.3 \%$ at Pădureni variety up to 24.8 by TD 1524-71) can be caused by high sensibility of those wheat genotype (Tab. 6).

The same instability of TKW can be observed in case of environment variability parameter $\left(\mathrm{s}^{2}\right)$ for TD 1524-71 genotype (94.19) compared with small value of this parameter at Marcius variety (21.32). The same data regarding the stability of thousand kernel weight was obtained by the coefficient of regression, highlighting those two cultivars (TD 1524-71 and Marcius) as a contrasting reaction. Deviations from regression $\left(\delta^{2}\right)$ and ecovalence $\left(\mathrm{W}^{2}\right)$ offers different information regarding the most stable or unstable genotypes, meanwhile the coefficient of determinations ranks the cultivars with the same responses (Alberts, 2004). 
Table 5. The stability parameters for number of grain per spike for 22 spring wheat genotypes

\begin{tabular}{cccccccc}
\hline Genotypes & $\overline{\mathbf{x}}$ & $\mathrm{CV}(\%)$ & $\mathrm{s}^{2}$ & $\mathrm{~b}$ & & $\mathrm{r}^{2}$ & $\mathrm{~W}^{2}$ \\
\hline SG 5-01 & 36.4 & 9.4 & 11.8 & 0.79 & 4.35 & 0.71 & 20.4 \\
\hline Prif 3 & 35.1 & 15.1 & 28.2 & 1.12 & 14.02 & 0.60 & 56.6 \\
\hline PF 70-35-4 & 34.4 & 13.0 & 20.0 & 1.09 & 4.99 & 0.80 & 20.4 \\
\hline SG V 773 & 34.1 & 7.5 & 6.6 & 0.32 & 6.56 & 0.21 & 56.9 \\
\hline Corso & 32.3 & 2.0 & 0.4 & 0.07 & 0.45 & 0.16 & 59.5 \\
\hline Jota & 32.1 & 9.9 & 10.1 & 0.38 & 10.20 & 0.20 & 66.0 \\
\hline Marcius & 32.1 & 15.3 & 24.2 & 0.88 & 17.27 & 0.43 & 70.6 \\
\hline SG 106-01 & 32.0 & 15.3 & 24.1 & 1.23 & 4.52 & 0.85 & 21.6 \\
\hline Lona & 32.0 & 23.4 & 56.1 & 1.97 & 4.48 & 0.94 & 82.5 \\
\hline Sigma & 31.9 & 13.8 & 19.3 & 0.89 & 10.71 & 0.56 & 43.1 \\
\hline Pădureni & 31.4 & 13.7 & 18.5 & 1.07 & 3.81 & 0.83 & 15.6 \\
\hline GK Tavasz & 31.2 & 14.5 & 20.3 & 0.08 & 25.29 & 0.00 & 157.8 \\
\hline Brome & 31.1 & 16.7 & 26.9 & 1.18 & 10.20 & 0.70 & 43.5 \\
\hline Henica & 30.9 & 7.7 & 5.6 & 0.03 & 7.04 & 0.00 & 91.4 \\
\hline Beloterkovskaia & 30.8 & 21.2 & 42.6 & 1.49 & 15.55 & 0.71 & 78.8 \\
\hline Jara & 30.8 & 17.8 & 30.0 & 1.42 & 3.32 & 0.91 & 25.6 \\
\hline Prif 4 & 30.7 & 21.9 & 44.1 & 1.72 & 4.94 & 0.91 & 55.7 \\
\hline Durom & 30.1 & 11.5 & 12.0 & 0.83 & 3.26 & 0.78 & 15.0 \\
\hline Silva & 29.5 & 16.5 & 23.8 & 1.02 & 12.20 & 0.59 & 48.6 \\
\hline TD 1524-71 & 29.3 & 24.9 & 53.3 & 1.78 & 13.02 & 0.80 & 93.8 \\
\hline Uralocica & 29.3 & 17.2 & 25.4 & 1.25 & 5.22 & 0.84 & 25.5 \\
\hline Mario & 29.3 & 18.0 & 27.8 & 1.37 & 3.11 & 0.91 & 22.1 \\
\hline Mean & 31.6 & 14.8 & 24.1 & 1.00 & 8.39 & 0.61 & 53.2 \\
\hline
\end{tabular}

Table 6. The stability parameters for thousand kernel weight of 22 spring wheat genotypes

\begin{tabular}{cccccccc}
\hline Genotypes & $\begin{array}{c}\overline{\mathbf{x}} \mathbf{x} \\
(\mathrm{g})\end{array}$ & $\mathrm{CV}(\%)$ & $\mathrm{s}^{2}$ & $\mathrm{~b}$ & & $\mathrm{r}^{2}$ & $\mathrm{~W}^{2}$ \\
& 39.1 & 24.8 & 94.2 & 1.56 & 1.18 & 0.99 & 64.50 \\
\hline TD 1524-71 & 38.1 & 13.1 & 24.8 & 0.78 & 1.57 & 0.95 & 15.41 \\
\hline Uralocica & 38.0 & 12.3 & 22.0 & 0.75 & 0.38 & 0.99 & 13.47 \\
\hline Pădureni & 36.5 & 13.2 & 23.0 & 0.76 & 1.09 & 0.96 & 15.54 \\
\hline Durom & 36.3 & 21.3 & 59.9 & 1.23 & 1.80 & 0.98 & 17.64 \\
\hline Prif 4 & 36.3 & 20.3 & 54.2 & 1.18 & 0.79 & 0.99 & 9.42 \\
\hline Lona & 36.0 & 22.4 & 64.5 & 1.28 & 1.83 & 0.98 & 22.51 \\
\hline Silva & 35.7 & 13.8 & 24.4 & 0.79 & 0.48 & 0.98 & 10.37 \\
\hline Brome & 35.7 & 14.9 & 28.2 & 0.84 & 1.67 & 0.95 & 11.88 \\
\hline Corso & 35.4 & 13.1 & 21.3 & 0.71 & 2.78 & 0.90 & 27.85 \\
\hline Marcius & 35.2 & 23.1 & 66.2 & 1.29 & 2.47 & 0.97 & 26.43 \\
\hline Mario & 34.9 & 13.5 & 22.3 & 0.75 & 0.60 & 0.98 & 14.16 \\
\hline SG 106-01 & 34.5 & 18.7 & 41.4 & 1.03 & 0.77 & 0.99 & 3.28 \\
\hline Jota & 34.5 & 18.3 & 39.6 & 0.98 & 3.19 & 0.94 & 12.82 \\
\hline Jara & 34.4 & 13.6 & 21.8 & 0.73 & 1.50 & 0.94 & 19.84 \\
\hline GK Tavasz & 34.3 & 16.9 & 33.6 & 0.93 & 0.61 & 0.99 & 3.44 \\
\hline PF 70-35-4 & 34.3 & 19.4 & 44.2 & 1.06 & 1.62 & 0.97 & 7.11 \\
\hline Henica & 33.7 & 24.1 & 66.0 & 1.29 & 3.09 & 0.96 & 27.98 \\
\hline Beloterkovskaia & 32.9 & 21.4 & 49.6 & 1.11 & 3.21 & 0.95 & 15.03 \\
\hline Prif 3 & 32.8 & 15.3 & 25.2 & 0.79 & 1.27 & 0.96 & 13.21 \\
\hline SG 5-01 & 32.8 & 34.6 & 0.94 & 0.40 & 0.99 & 2.20 \\
\hline SG V 773 & 32.8 & 17.9 & 34.6 & 1.22 & 3.16 & 0.96 & 21.94 \\
\hline Sigma & 32.8 & 23.6 & 59.7 & 1.22 & 0.97 & 17.09 \\
\hline Mean & 35.2 & 18.0 & 41.7 & 1.00 & 1.61 & & \\
\hline & & & & & & & \\
\hline & & & & & &
\end{tabular}


Table 7. The stability parameters for spikes density per unit area for 22 spring wheat genotypes

\begin{tabular}{|c|c|c|c|c|c|c|c|}
\hline Genotypes & $\overline{\mathbf{x}}$ & CV (\%) & $\mathbf{s}^{2}$ & $\mathbf{b}$ & & $\mathbf{r}^{2}$ & $\mathbf{W}^{2}$ \\
\hline SG 106-01 & 564.6 & 38.9 & 48237.6 & 1.30 & 2895.6 & 0.95 & 23874.1 \\
\hline SG V 773 & 558.7 & 41.7 & 54158.3 & 1.40 & 1513.4 & 0.98 & 27430 \\
\hline Jota & 548 & 33.8 & 34306.3 & 1.09 & 2766.7 & 0.94 & 12116.8 \\
\hline Henica & 544.5 & 39.5 & 46219.5 & 1.27 & 2946.5 & 0.95 & 21804.1 \\
\hline Silva & 542 & 33.9 & 33782.6 & 1.09 & 1616.3 & 0.96 & 7684.3 \\
\hline Jara & 530.8 & 29.0 & 23719.2 & 0.89 & 2917.1 & 0.90 & 13364.9 \\
\hline Uralocica & 530.3 & 30.2 & 25599.4 & 0.96 & 652 & 0.98 & 2798.7 \\
\hline Prif 3 & 518.9 & 37.9 & 38731.7 & 1.19 & 591.1 & 0.99 & 7141.3 \\
\hline Mario & 512.8 & 24.9 & 16345 & 0.76 & 959.2 & 0.95 & 11784.4 \\
\hline PF 70-35-4 & 507.6 & 38.2 & 37545.7 & 1.17 & 428.3 & 0.99 & 5677.4 \\
\hline Sigma & 507.5 & 25.5 & 16774.3 & 0.78 & 523.0 & 0.98 & 8866.5 \\
\hline Prif 4 & 506.4 & 33.9 & 29402.8 & 1.04 & 219.6 & 0.99 & 1072.4 \\
\hline SG 5-01 & 505.7 & 30.3 & 23413.6 & 0.92 & 442.5 & 0.99 & 2581.6 \\
\hline Lona & 500.3 & 25.8 & 16665.8 & 0.77 & 608.0 & 0.97 & 9464.2 \\
\hline Brome & 498.7 & 33.5 & 27929.5 & 1.01 & 411.4 & 0.99 & 1659.3 \\
\hline Pădureni & 494.6 & 31.4 & 24051.6 & 0.93 & 964.1 & 0.97 & 4586.5 \\
\hline Corso & 489.2 & 37.0 & 32829.8 & 1.08 & 1604.1 & 0.96 & 7251 \\
\hline Beloterkovskaia & 488.8 & 23.3 & 13015.5 & 0.66 & 1664.3 & 0.90 & 22671.7 \\
\hline TD 1524-71 & 486.2 & 35.4 & 29546.4 & 1.02 & 1489.0 & 0.96 & 6022.5 \\
\hline Marcius & 475.9 & 37.1 & 31209.3 & 1.01 & 4654.6 & 0.88 & 18614.5 \\
\hline Durom & 470.5 & 25.4 & 14325.7 & 0.70 & 1524 & 0.91 & 18702.6 \\
\hline GK Tavasz & 469.8 & 34.5 & 26276 & 0.98 & 326.4 & 0.99 & 1362.3 \\
\hline Mean & 511.4 & 32.8 & 29276.6 & 1.00 & 1441.7 & 0.97 & 10751.4 \\
\hline
\end{tabular}

Ayed et al. (2016) have obtained higher value for deviation from regression and lower value for coefficient of determination in his study using durum wheat, bread wheat and barley. A small coefficient of variability was founded by Chang et al. (2010) analyzing 13 cultivars in a multilocation study in China.

The density of spikes per square meter depends mainly by soil water reserves, tillering capacity and also in some wise by grain size (Madani et al., 2010). The average of spikes density per square meter was close by the number of grains seeded, which means that the capacity of spring wheat to make some fertile tillers are very low. As a stability parameter for this element of productivity, the coefficient of variability, environment variance and regression coefficient highlight the same genotypes as a stable - Beloterkovskaia and unstable -SG V 773 (Tab. 7).
Deviations from regression parameter varied from 219.6 for Prif 4 to 4656.6 by Marcius as the most instable cultivars for spikes density per square meter, strengthened data also by the coefficient of determination (0.88). Also, Wrike's coefficient had large variations from 1072.4 by Prif 4 genotype to 23874.1 for SG 106-01. Aycicek and Yildirim (2006) have obtained superior value for spike number per unit area, but similar results for $b_{i}$, and $r^{2}$ in a two years study for high-yielding and stable wheat cultivar in two growing locations.

The significant positive correlation $(\mathrm{P} \leq 0.05)$ was obtained between mean grain yield and environment variance- $\mathrm{s}^{2}$ (tab. 8). A stronger relationship ( $\mathrm{P} \leq 0.01$ ) was observed between regression coefficient and grain yield, coefficient of regression and variability coefficient, and also with $\mathrm{s}^{2}$. 
Table 8. Correlations between stability parameters for different quantitative parameters

\begin{tabular}{|c|c|c|c|c|c|c|}
\hline $\begin{array}{l}\text { Correlated } \\
\text { character }\end{array}$ & $\mathrm{CV}$ & & $\mathrm{s}^{2}$ & $\mathrm{~b}$ & $r^{2}$ & $\mathrm{~W}^{2}$ \\
\hline \multicolumn{7}{|c|}{ Grain yield $\left(\mathrm{t} \mathrm{ha}^{-1}\right)$} \\
\hline$\overline{\mathbf{x}}$ & 0.22 & $0.53^{*}$ & $0.54^{* *}$ & $0.55^{* *}$ & 0.04 & 0.11 \\
\hline $\mathrm{CV}$ & 1 & $0.93^{* *}$ & $0.93^{* *}$ & $0.94 * *$ & 0.18 & 0.34 \\
\hline $\mathrm{s}^{2}$ & & 1 & $0.99 * *$ & $1.00^{* *}$ & 0.20 & 0.39 \\
\hline \multirow[t]{2}{*}{$\mathrm{b}$} & & & 1 & $0.99^{* *}$ & 0.31 & 0.25 \\
\hline & & & & 1 & 0.18 & 0.34 \\
\hline $\mathrm{r}^{2}$ & & & & & 1 & $-0.62^{* *}$ \\
\hline $\mathrm{W}^{2}$ & & & & & & 1 \\
\hline \multicolumn{7}{|c|}{ Number of grains/spike } \\
\hline$\overline{\mathbf{x}}$ & $-0.47^{*}$ & -0.35 & -0.29 & -0.34 & -0.20 & -0.12 \\
\hline $\mathrm{CV}$ & 1 & $0.96^{* *}$ & $0.89^{* *}$ & $0.99 * *$ & $0.67^{* *}$ & 0.13 \\
\hline $\mathrm{s}^{2}$ & & 1 & $0.89^{* *}$ & $0.97^{* *}$ & $0.63^{* *}$ & 0.20 \\
\hline \multirow[t]{2}{*}{$\mathrm{b}$} & & & 1 & $0.90^{* *}$ & $0.90^{* *}$ & -0.27 \\
\hline & & & & 1 & $0.68^{* *}$ & 0.12 \\
\hline $\mathrm{r}^{2}$ & & & & & 1 & $-0.61^{* *}$ \\
\hline $\mathrm{W}^{2}$ & & & & & & 1 \\
\hline \multicolumn{7}{|c|}{ Thousand kernel weight (g) } \\
\hline$\overline{\mathbf{x}}$ & -0.16 & 0.13 & 0.08 & 0.07 & 0.18 & $0.45^{*}$ \\
\hline $\mathrm{CV}$ & 1 & $0.95^{* *}$ & $0.97^{* *}$ & $0.97^{* *}$ & 0.27 & $0.43^{*}$ \\
\hline $\mathrm{s}^{2}$ & & 1 & $0.99^{* *}$ & $0.99^{* *}$ & 0.31 & $0.63^{* *}$ \\
\hline \multirow[t]{2}{*}{$\mathrm{b}$} & & & 1 & $1.00^{* *}$ & 0.35 & $0.55^{* *}$ \\
\hline & & & & 1 & 0.32 & $0.56^{* *}$ \\
\hline $\mathrm{r}^{2}$ & & & & & 1 & -0.11 \\
\hline \multirow[t]{2}{*}{$\mathrm{W}^{2}$} & & & & & & 1 \\
\hline & \multicolumn{6}{|c|}{ Spikes/density per unit area } \\
\hline$\overline{\mathbf{x}}$ & 0.38 & $0.65^{* *}$ & $0.62^{* *}$ & 0.24 & 0.13 & 0.37 \\
\hline $\mathrm{CV}$ & 1 & $0.94^{* *}$ & $0.96^{* *}$ & 0.27 & 0.26 & 0.12 \\
\hline $\mathrm{s}^{2}$ & & 1 & $0.99 * *$ & 0.31 & 0.23 & 0.33 \\
\hline \multirow{2}{*}{$\mathrm{b}$} & & & 1 & 0.23 & 0.33 & 0.19 \\
\hline & & & & 1 & $-0.80^{* *}$ & $0.66^{* *}$ \\
\hline $\mathrm{r}^{2}$ & & & & & 1 & $-0.61^{* *}$ \\
\hline $\mathrm{W}^{2}$ & & & & & & 1 \\
\hline
\end{tabular}

* significant at the 0.05 probability level

** significant at the 0.01 probability level

Deviation from regression can be strongly associated with mean, coefficient of variability, environment variance and coefficient of regression.

A negative relation $(\mathrm{R}=-0.62)$ was obtained between Wricke's coefficient and determination coefficient.

The stability parameters for number of grains per spike were highly correlated for the most cases except the relations with grain yield and Wricke's coefficient, where in case of relationship between grain mean and coefficient of variability $(-0.47)$, coefficient of determination and Wricke ecovalence appear a strongly significant negative correlation (-0.61). Similar results were obtained by Akcura et al. (2006) for durum wheat.
For thousand kernel weight the association of stability parameters was different, probably caused by high genetic determination of this character.

Thus, some strong relations were maintained while the negative relation between ecovalence and $\mathrm{r}^{2}$ were poorly. In this case, the high correlation between ecovalence and deviation from regression suggest that the covariance usually explains only a small part of $\mathrm{W}^{2}$ (Hill et al., 1998).

High negative significance was noted between $r^{2}$ and , and between $r^{2}$ and Wricke's ecovalence in case of spikes density per square meter, while between $\mathrm{s}^{2}$ and mean value, $\mathrm{s}^{2}$ and $\mathrm{CV}, \mathrm{b}$ and mean, $\mathrm{b}$ and $\mathrm{CV}$, and $\mathrm{b}$ and $\mathrm{s}^{2}$ was recorded a high positive 
correlation which means that the stability can be appreciated by each of these parameters.

\section{Conclusion}

Our research demonstrated the applicability of stability parameters to other quantitative traits than yield, such as number of grains per spike, thousand kernel weight and spike density per unit area. Correlations between stability parameters showed that any of stability indices could be used without to lose the yield efficiency.

The genotypes: SG 106-01, SG 5-01, Prif 3, Sigma, Jota, Henica, Lona, Corso and Marcius, indicated high stability and adaptation. These genotypes can be recommended for cultivation in Transylvanian Plain conditions, or in other European environments with appropriate climatic factors.

This research did not receive any specific grant from funding agencies in the public, commercial, or not-for-profit sector.

\section{References}

1. Akura M, Kaya Y, Taner S (2005). Genotype-Environment Interaction and Phenotypic Stability Analysis for Grain Yield of Durum Wheat in the Central Anatolian Region, Turk J Agric For. 29: 369-375.

2. Akura M, Kaya Y, Taner S, Ayranci R. (2006). Parametric stability analyses for grain yield of durum wheat, Plant Soil Envoronment, 52 (6):254-261.

3. Alberts MJA (2004). A comparison of statistical methods to describe genotype $\mathrm{x}$ environment interaction and yield stability in multi-location maize trials, Magister Scientiae Agriculturae Thesis, University of the Free State Bloemfontein.

4. Amin M, Tila M, Khan AJ, Irfaq M, Ali A, Tahir GR (2005). Yield stability of spring wheat (Triticum aestivum L.) in the North West Frontier Province, Pakistan; Songklanakarin J. Sci. Technol., 27(6) : 1147-1150.

5. Anderson WK, van Burgel AJ, Sharma DL, Shakcley BJ, Zaicou-Kunesch CM, Miyan MS, Amjad M (2011).Assessing specific agronomic response of wheat cultivars in a winter rainfall environment Crop \& Pasture Science 62: 115- 124.

6. Anwar JM, Ali MA, Hussain M, Sabir W, Khan MA, Zulkiffal M, Abdullah M. (2009) Assessment of yield criteria in bread wheat through correlation and path analysis. J Animal Plant Sci. 19: 185-188.

7. Aycicek M, Yildirim T (2006). Adaptability Performances of Some Bread Wheat (Triticum aestivum L.) Genotypes in The Eastern Region of Turkey, International Journal of Science \& Technology, Vol.1, no 2:83-89.

8. Ayed S, Othmani A, Chaieb N, Bechrif S, Rezgui M, Younes MB (2016). Assesment of adaptability and Stability of six Tunisian cereal genotypes under rainfed conditions and at two semi-arid environments, European Scietific Journal, 12: 122-132.

9. Bantayehu M (2009) Analysis and correlation of stability parameters in malting barley, African Crop Science Journal, 17(3): 145-153.

10. Barros HB, Sediyama T, Cruz CD, Teixeira RC, Reis MS (2010). Análise de adaptabilidade estabilidade em soja (Glycine max L) em Mato Grosso. Ambiência 6: 75-88.

11. Becker HC (1981). Biometrical and empirical relations between different concepts of phenotypic stability, in Gallais, A., ed. Quantitative Genetics and Breeding Methods, Versailles, INRA, pp. 307-314.

12. Castillo D, Matus I, del Pozo A, Mellado M. (2012). Adaptability and genotype $\mathrm{x}$ environment interaction of spring wheat cultivars in Chile using regression analysis, AMMI, and SREG, Chilean Journal of Agricultural Research, 72 (2): 167-174.

13. Chang L, Chai SX, Yang DL, Lu QL (2010). Variation analysis on the grain yield and main agronomic traits of spring wheat in rainfed regions of China, The journal of applied ecology, 21(11): 2821-9.

14. Cruz CD, Regazzi AJ, Carneiro PCS (2012). Modelos Biométricos Aplicados ao Melhoramento Genético. Editora UFV, Viçosa.

15. Dewi AK, Chozin MA, Triwidodo H, Aswidinnoor H (2014). Genotype $\mathrm{x}$ environmet interaction, and stability analysis in lowland rice promising genotypes, International Journal of Agronomy and Agricultural Research, 5(5): 7484.

16. Donald CM (1968). The breeding of crop ideotype, Euphytica, 17: 485-403.

17. Eberhart SA, Russell WA (1966). Stability parameters for comparing varieties. Crop Sci., 6: 36-40.

18. Finlay KW, Wilkinson GN (1963). The analysis of adaptation in a plant breeding programme, Australian J. Agric. Sci., 14: 742-754.

19. Foulkes MJ, Slafer GA, Davies WJ, Berry PM, SylvesterBradley R, Martre P, Calderini DF, Griffiths S, Reynolds MP (2011). Raising yield potential of wheat. III. Optimizing partitioning to grain while maintaining lodging resistance. J. Exp. Bot., 62: 469-486.

20. Gómez-Becerra H.F, Morgounov A, Abugalieva A (2006). Evaluation of grain yield stability, reliability and cultivar recommendations in spring wheat (Triticum aestivum. L.) from Kazakhstan and Siberia, Journal of Central European Agriculture, 7(4): 649-660.

21. Hill J, Becker HC, Tigerstedl PMA (1998). Quantitative and ecological aspects of plant breeding, Plant Breeding series 4, Ed. Chapman \& Hall.

22. Kaur V, Behl RK (2010). Grain yield in wheat as affected by short periods of high temperature, drought and their interaction during pre- and post- anthesis stages, Cereal Res. Commun., 38: 514-520.

23. Kaya Y, Akcura M (2014). Effects of genotype and environment on grain yield and quality traits in bread wheat (T.aestivum L.), Food Sci. Technol (Campinas), 34(2): 215-225. 
24. Kiliç $H$ (2012). Assessment of parametric and nonparametric methods for selecting stable and adapted spring bread wheat genotypes in multi-environments, The Journal of Animal \& Plant Sciences, 22 (2): 390-398.

25. Kilic H, Akcura M, Aktaş H (2010). Assessment of Parametric and Non-Parametric Methods for Selecting Stable and Adapted Durum Wheat Genotypes in MultiEnvironments Not. Bot. Hort. Agrobot. Cluj, 38 (3): 271279.

26. Lobell BD, Sibley A, Ortiz-Monasterio JI (2012). Extreme heat effects on wheat senescence in India. Nat. Clim. Change, 2:186-189.

27. Reisch L, Eberle U, Lorek S (2013). Sustainable food consumpltion: an overview of contemporary issues and policies, Sustainability: Science, Practice \& Policy 9 (2):725.

28. Madani A, Rad AS, Pazoki A, Nourmohammadi G, Zarghami $\mathrm{R}$ (2010). Wheat (Triticum aestivum L.) grain filling and dry matter partitioning responses to source: sink modifications under postanthesis water and nitrogen deficiency, Acta Sci., Agron. (Online) 32(1): 322-329.

29. Mustățea P, Săulescu NN, Ittu G, Păunescu G, Voinea L, Stere I, Mîrlogeanu S, Constantinescu E, Năstase D (2009). Grain yield and yield stability of winter wheat cultivars in contrasting weather conditions, Romanian Agricultural Research, 26: 1-8.

30. Pinthus MJ (1973). Estimates of genotypic value: a proposed method, Euphytica, 22: 345-351.

31. Saad FF, El-Mohsen AA, Al-Soudan IH (2013). Parametric Statistical Methods for Evaluating Barley Genotypes in Multi-Environment Trials, World Essays Journal, vol. 1(4): 125-136.

32. Sapega VA, Tursumbekova GS (2013). Estimation of spring wheat varieties in terms of yield and adaptability parameters, Russian Agricultural Science, 39(5-6): 403408.

33. Semenov MA, Halford NG (2009). Identifying target traits and molecular mechanisms for wheat breeding under a changing climate. J. Exp. Bot., 60: 2791-2804.
34. Semenov MA, Shewry PR (2011). Modelling Predicts that Heat Stress, not Drought, will Increase Vulnerability of Wheat in Europe Scientific Reports, 1: 66.

35. Semenov MA, Stratonovitch P, Alghabari F, Gooding MJ (2014). Adapting wheat in Europe for climate change, Journal of Cereal Science., 59 (3): 245-256.

36. Sillmann J, Roeckner E (2008). Indices for extreme events in projections of anthropogenic climate change. Clim. Change, 86: 83-104.

37. Showemimo FA (2007). Grain yield response and stability indices in sorghum (Sorghum bicolor (L.) Moench), Communications in Biometry and Crop Science, 2(2): 68-73.

38. Tsenov N, Gubatov T, Dobrinka Atanasova, Margarita Nankova, Albena Ivanova (2014). Genotype x Environment Effects on The Productivity Traits of Common Wheat (Triticum aestivum L.) II. Analysis of Genotype Reaction, Turkish Journal of Agricultural and Natural Sciences, Special Issue 1: 1198-1208.

39. Wricke G (1962). Über eine methode zur erfassung der őkologishen streubreite in feldversuchen, $\mathrm{Z}$. Pflanzenzǜcht., 47: 92-96.

40. Wu J, Glover J., Mueller N (2014). Check Based Stability AnalysisMethod and Its Application to Winter Wheat Variety Trials, 26th Conference of Applied Statistics in Agriculture, Kansas State University, 6: 102-109. 25th Conference of Applied Statistics in Agriculture

41. Yagdi K. (2009). Path coefficient analysis of some yield components in durum wheat (Triticum durum Desf,) Pak. J. Botany 41: 745-751.

42. Zheng B, Chenu K, Dreccer MF, Chapman SC (2012). Breeding for the future: what are the potential impacts of future frost and heat events on sowing and flowering time requirements for Australian bread wheat (Triticum aestivium L.) varieties? Glob. Change Biol., 18: 2899-2914. 